\title{
ARTIKELEN
}

\section{Migrant smuggling in the Mediterranean}

\section{An excludable act under article $1 \mathrm{~F}(\mathrm{~b})$ Refugee Convention?}

Anne Aagten

\begin{abstract}
Article $1 F(b)$ Refugee Convention prescribes that the Refugee Convention does not apply if there are serious reasons to consider that the asylum seeker has been involved in serious non-political crimes. First, this contribution will consider whether migrant smuggling in the Mediterranean can be considered as such. Second, it will discuss whether the various forms of participation in Mediterranean migrant smuggling operations fulfill the requirements for individual responsibility and may trigger the application of article $1 F(b)$ Refugee Convention.
\end{abstract}

\section{Introduction}

Migrants and refugees have crossed the Mediterranean for decades. The exact numbers fluctuate, due to a variety of factors, including circumstances in the country of origin and transit, geopolitical developments and European policies, for example the deal between the European Union (EU) and Turkey. ${ }^{1}$ In 2015, as a consequence of the spread of conflict in a wide range of countries in the Middle East and Sub-Saharan Africa, the number of migrants travelling to Europe has increased dramatically. ${ }^{2}$ An estimated $90 \%$ of all migrants used the services of smugglers. ${ }^{3}$ Smuggling networks operate in a highly segmented market, offering different smuggling services, varying from full packages, which cover the whole journey and may even include falsified and fraudulent documents, to the pay-asyou-go services. ${ }^{4}$ The major migratory routes for crossing the Mediterranean Sea

1 EU-Turkey Statement, European Council 18 March 2016, <www.consilium.europa.eu/en/press/ press-releases/2016/03/18-eu-turkey-statement/>; Human Rights Watch, The Mediterranean Migration Crisis, Why People Flee, What the EU Should Do, Human Rights Watch 19 June 2015, p. 1.

2 Factsheet IOM and Counter Migrant Smuggling, International Organization on Migration 19 April 2016, <www.iom.int/news/iom-releases-global-migration-trends-2015-factsheet>; Frontex, Risk Analysis for 2016, Warsaw: Frontex 2016, p. 14.

3 Europol, Migrant Smuggling in the EU, Europol 2016, p. 4; Europol INTERPOL, Migrant Smuggling Networks: Joint Europol-INTERPOL Report, Europol INTERPOL 2016, p. 6.

4 N. Abel Aziz, P. Monzini and F. Pastore, The Changing Dynamics of Cross-Border Human Smuggling and Trafficking in the Mediterranean, New-Med Research Network 2015; L. Shelley, Human Smuggling and Trafficking into Europe: A Comparative Perspective, MPI Reports February 2014; Migration Policy Debates, Organization for Economic Cooperation and Development 9 December 2015 <www.oecd.org/migration/Can\%20we\%20put\%20an\%20end\%20to\%20human\%20smuggling. pdf>, p. 6. 
from Africa to Europe are the Western Mediterranean Route (from Morocco to Spain), the Central Mediterranean Route (from Tunisia and Libya to Malta and Italy), and the Eastern Mediterranean Route (from Egypt and Turkey to Italy and Greece). ${ }^{5}$ Unfortunately, numerous migrants do not survive their dangerous journey. In 2015, the number of arrivals by sea reached an unprecedented amount of $1,015,078$ individuals of which an estimated 3,771 passed away or are still missing. ${ }^{6}$ In 2016, an estimated 388,000 migrants attempted to reach the European continent, of which approximately 5,100 lost their lives or are missing. ${ }^{7}$ In 2017, between 170,000 and 180,000 individuals took the risk to cross the Mediterranean. ${ }^{8}$ From this group, an estimated 3,000 people perished or are missing. ${ }^{9}$

Significantly, empirical research on migrant smuggling has revealed that asylum seekers themselves are often involved in the operations. ${ }^{10}$ Hence, there certainly exists a possibility that the perpetrators of migrant smuggling are welcomed as refugees in the countries of destination and enjoy the rights flowing from refugee protection. However, article 1F of the 1951 Convention Relating to the Status of Refugees (Refugee Convention) provides the possibility to exclude those individuals who are deemed 'undeserving' of refugee protection. The categories of article $1 \mathrm{~F}$ are often referred to as the exclusion clauses. ${ }^{11}$ They state that the provisions of the Refugee Convention 'shall not apply to any person with respect to whom there are serious reasons for considering that:

a He has committed a crime against peace, a war crime, or a crime against humanity, as defined in the international instruments drawn up to make provision in respect of such crimes;

5 Europol INTERPOL, p. 6; N. Abel Aziz et al., p. 19; L. Achilli, 'Irregular Migration to the EU and Human Smuggling in the Mediterranean. The Nexus between Organized Crime and Irregular Migration', Mediterranean Yearbook 2016.

6 Operational Portal Refugee Situation, UNHCR, <http://data2.unhcr.org/en/situations/ mediterranean>.

7 Ibid; Migration Flows Europe, IOM, <http://migration.iom.int/europe/>.

8 Ibid; ibid; European Council on Refugees and Exiles (ECRE), Mediterranean still the busiest and deadliest gate to Europe, ECRE: December 2017, <www.ecre.org/mediterranean-still-the-busiestand-deadliest-gate-to-europe/?utm_source=ECRE+Newsletters\&utm_campaign=8739dc486f-

EMAIL_CAMPAIGN_2018_01_118utm_medium=email\&utm_term=0_3ec9497afd-8739dc486f -422314489>.

9 Operational Portal Refugee Situation, UNHCR; Migration Flows Europe, IOM.

10 Abel Aziz et al., p. 59; A. Triandafyllidou and T. Maroukis, Migrant Smuggling: Irregular Migration from Asia and Africa to Europe, (Palgrave Macmillan 2012), p. 105, 134; I. van Liempt, Navigating Borders: Inside Perspectives on the Process of Human Smuggling into the Netherlands, (PhD Dissertation, Amsterdam University Press 2007), pp. 124-125; L. Achilli, 'The Smuggler: Hero or Felon?', (Migration Policy Centre, Policy Brief 2015), p. 7; G. Sanchez, 'Critical Perspectives on Clandestine Migration Facilitation: An Overview of Migrant Smuggling Research’, (Journal on Migration and Human Security 2017), p. 15; L. Achilli, 'The "Good" Smuggler: The Ethics and Morals of Human Smuggling among Syrians', (AAPSS March 2018), p. 87.

11 UNHCR, Handbook and Guidelines on Procedures and Criteria for Determining Refugee Status, (Handbook) (Geneva 2011), para. 143; UNHCR, Guidelines on International Protection: Application of the Exclusion Clauses: Article $1 F$ of the 1951 Convention Relating to the Status of Refugees, (Guidelines) (Geneva 4 September 2003), para. 3; UNHCR, Background Note on the Application of the Exclusion Clause: Article 1F of the 1951 Convention Relating to the Status of Refugees, (Background Note) (Geneva: 4 September 2003), para. 1. 
b He has committed a serious non-political crime outside the country of refuge prior to his admission to that country as a refugee; or

c He has been guilty of acts contrary to the purposes and principles of the United Nations. ${ }^{12}$

The rationale behind these exclusion clauses is twofold. Firstly, the thought is that certain acts are so severe that they have to deprive their perpetrators of protection as refugees. ${ }^{13}$ Secondly, the clauses have to ensure that the asylum system is not being abused by the perpetrators in order to avoid accountability for their acts. ${ }^{14}$ Nonetheless, as the clauses contain exceptions to human rights guarantees, they must be interpreted restrictively. ${ }^{15}$ This is particularly necessary as exclusion has serious consequences for an individual, as he ${ }^{16}$ falls outside the protective framework of the Refugee Convention. Lastly, the grounds for exclusion are formulated exhaustively in the Refugee Convention. ${ }^{17}$ There is room for interpretation, but article $1 \mathrm{~F}$ cannot be supplemented with additional criteria.

In 2000, the United Nations Convention against Transnational Organized Crime was concluded to serve and enhance international cooperation to fight transnational organized crime. ${ }^{18}$ The instrument has three additional protocols, one of which specifically aims at combatting migrant smuggling. ${ }^{19}$ For the first time an internationally agreed definition on migrant smuggling was provided, which is the following:

'the procurement, in order to obtain, directly or indirectly, a financial or other material benefit, of the illegal entry of a person into a State Party of which the person is not a national or permanent resident.'20

In the meantime, since the adoption of the Schengen Convention, the European Union strengthened its efforts to combat irregular migration. This resulted in a Directive and a Framework Decision, both adopted in 2002. ${ }^{21}$ Article 1 of the

12 Convention Relating to the Status of Refugees (Refugee Convention) adopted 28 July 1951, entered into force 22 April 1954 (189 UNTS 137) art. 1F.

13 Ibid; Guidelines, para. 2; Background Note, para. 3.

14 Guidelines ibid; Background Note ibid.

15 Ibid; ibid, para. 4.

16 In this contribution 'he' also refers to 'she'.

17 Guidelines, para. 3.

18 United Nations Convention on Transnational Organized Crime (UNTOC), United Nations General Assembly, adopted 15 November 2000, entered into force 29 September 2003.

19 Protocol against the Smuggling of Migrants by Land, Sea and Air supplementing the United Nations Convention on Transnational Organized Crime (Smuggling Protocol), United Nations General Assembly, adopted 15 November 2000, entered into force 28 January 2004.

20 Smuggling Protocol, art. 3(a); art. 6(1)(b) and (c) also criminalizes offences committed for the purpose of enabling the smuggling of migrants, providing and/or producing fraudulent documents and enabling illegal residence.

21 Council Directive 2002/90/EC of 28 November 2002 defining the facilitation of unauthorised entry, transit and residence (Directive 2002/90/EC) (2002, L 328/17); Council Framework Decision 2002/946/JHA of 28 November 2002 strengthening of the penal framework to prevent the facilitation of unauthorised entry, transit and residence (Framework Decision) (2002, L 328/1). 
Directive obliges the EU Member States to impose 'effective and proportionate sanctions and dissuasive sanctions' on the following:

'(a) any person who intentionally assists a person who is not a national of a Member State to enter, or transit across, the territory of a Member State in breach of the laws of the State concerned on the entry or transit of aliens' ${ }^{22}$

When comparing the two definitions, the elements of the offense are different. Most importantly, the Smuggling Protocol focuses on conduct involving assisted illegal entry, when undertaken for profit or a material benefit. On the contrary, Directive 2002/90 also focuses on transit. Besides, in the definition in Directive 2002/90, the component of financial or material benefit is omitted. Therefore, the scope of the definition in Directive 2002/90 is larger than the one in the Smuggling Protocol, and probably also covers humanitarian operations that the drafters of the Smuggling Protocol carefully prevented to codify. ${ }^{23}$

With the creation of a Common European Asylum System (CEAS) in order to develop common standards for asylum for the EU Member States, the Qualification Directive was introduced which resembles the legislative framework for granting international protection. At the European level, this includes refugee protection and subsidiary protection. Article 1F Refugee Convention was implemented in article 12(2) and article 17(1) Qualification Directive. ${ }^{24}$

This contribution will address whether migrant smuggling can be considered a serious non-political crime falling within the scope of article $1 \mathrm{~F}(\mathrm{~b})$ Refugee Convention. The $1 \mathrm{~F}(\mathrm{~b})$ clause is explicitly selected as the nature of migrant smuggling is more suitable to fall within the terms of this clause as opposed to articles $1 \mathrm{~F}(\mathrm{a})$ and $1 \mathrm{~F}(\mathrm{c})$. This analysis will involve two stages. ${ }^{25}$ First, with the help of empirical research on migrant smuggling in the Mediterranean, it will be analyzed whether migrant smuggling can be considered a serious non-political crime (see paragraph 2). Second, it will be discussed which conduct involved in migrant smuggling in

Council Directive 2002/90/EC, art. 1(a); art. 1(b) criminalizes any person who, for financial gain, intentionally assists a person who is not a national of a Member State to reside within the territory of a Member State in breach of the laws of the State concerned on the residence of aliens.

23 Interpretative Notes, Travaux Préparatoires of the Negotiations for the Elaboration of the United Nations Convention Against Transnational Organized Crime and the Protocols Thereto (2006) at p. 17.

24 Directive 2011/95 of the European Parliament and the Council on standards for the qualification of third-country national or stateless persons as beneficiaries of international protection, for a uniform status of refugees or for persons eligible for subsidiary protection, and for the content of the protection granted (Qualification Directive) (2011, L 337/9) art. 12(2) and 17(1); However, both worldwide and at EU level, practice increasingly tends to widen the circumstances in which art. $1 \mathrm{~F}$ applies, see for instance: G. Goodwin-Gill and J. McAdam, The Refugee in International Law, (OUP 2007), pp. 416-417; Sarah Singer, 'Exclusion from Refugee Status: Asylum Seekers and Terrorism in the UK', (Working Paper, Centre for Criminal Justice and Human Rights, University College Cork 2012).

25 See for a similar approach: CJEU 9 November 2010, nr. C-59/09 and C-101/09 (B and D), para. 80-87; CJEU 31 January 2017, nr. C-573/14 (Lounani), para. 62-80. 
the Mediterranean can establish individual responsibility and trigger the application of article $1 \mathrm{~F}(\mathrm{~b})$ (see paragraph 3 ).

\section{Migrant smuggling as a serious non-political crime}

At the outset, it must be ascertained whether acts constituting migrant smuggling in general can be read into the wordings of article $1 \mathrm{~F}(\mathrm{~b})$. In this paragraph, it will be assessed what the content and scope of the wordings of article $1 \mathrm{~F}(\mathrm{~b})$ entail and whether acts constituting migrant smuggling can be considered to fall within this particular content and scope of serious non-political crimes.

\subsection{The wordings of article $1 F(b)$}

Article $1 \mathrm{~F}(\mathrm{~b})$ provides that a person is excluded from protection under the Refugee Convention where there are serious reasons for considering that "he has committed a serious non-political crime outside the country of refuge prior to his admission to that country as a refugee.'26 'Prior to his admission to that country as a refugee' seems to be a straightforward formulation. Nonetheless, for the term 'refugee' to be applicable, a qualification exercise must have taken place with the outcome that this individual is actually a refugee. ${ }^{27}$ This interpretation is confirmed in article 12(2) of the Qualification Directive ${ }^{28}$ where admission as a refugee is interpreted as the moment a residence permit is granted after according refugee status.

Nonetheless, neither 'serious crimes' nor 'political crimes' have been defined in the Refugee Convention or have been given universally accepted definitions in other normative instruments. As the words are not self-applying, the States Parties have a wide margin of interpretative discretion to exercise on the basis of the ordinary meaning and objectives of the Refugee Convention. ${ }^{29}$ Therefore, on the basis of UNHCR guidelines ${ }^{30}$ and European and domestic case law, the scope and content of these concepts will be established. Afterwards, it will be analyzed whether migrant smuggling in the Mediterranean falls within this particular content and scope of article $1 \mathrm{~F}(\mathrm{~b})$ by involving the relevant legal instruments,

Ibid.

27 Vienna Convention on the Law of Treaties, adopted 23 May 1969, entered into force 27 January 1980, (331 UNTS 1155) (Vienna Convention) art. 31(1); Qualification Directive, art. 2(d)(e); Refugee Convention, art. 1A.

28 Qualification Directive, art. 12(2).

29 Vienna Convention, art. 31(1).

30 UNHCR documents do not provide for legally binding provisions. Nonetheless, they are considered highly authoritative and are frequently relied upon by international, European and domestic courts. 
domestic case law about migrant smuggling and article $1 \mathrm{~F}^{31}$ and empirical research on migrant smuggling.

\subsection{Migrant smuggling as a 'serious crime'}

The UNHCR acknowledges the interpretative problems by recognizing that the notion of 'crime' has divergent connotations in different legal systems. ${ }^{32}$ Nonetheless, as mentioned in paragraph 1 , migrant smuggling comprises a transnational criminal act that is defined in the Smuggling Protocol. ${ }^{33}$ Additionally, the Smuggling Protocol requires its States Parties to adopt legislative and other necessary measures to establish migrant smuggling as a criminal offence. ${ }^{34}$ Secondly, for the purposes of enabling migrant smuggling, the production of fraudulent travel or identity documents and the procurement, provision or possession of such a document must be established as criminal offences. ${ }^{35}$ Thirdly, enabling an individual who does not comply with the requirements for legal stay in the State concerned is also criminalized. ${ }^{36}$ Crucially, the EU as international organization and all the EU Member States except for Ireland have ratified the Smuggling Protocol. ${ }^{37}$

Furthermore, as discussed in paragraph 1, the European Council Directive 2002/90/EC also obliges the criminalization of intentionally assisting a person who is not a national of a Member State to enter, or transit across, the territory of a EU Member State. ${ }^{38}$ Accordingly, all EU Member States adopted national legislation that establishes this conduct as a criminal offence and are obliged to impose appropriate criminal penalties. ${ }^{39}$ Therefore, it can be concluded that migrant smuggling is considered a crime.

The main reason for the controversy surrounding 'serious' is the absence of legal instruments defining which crimes are serious and which are not. Unlike crimes mentioned under article $1 \mathrm{~F}(\mathrm{a})$, which clearly have a link with international criminal law that serves as an interpretative tool, it remains ambiguous as to how the term 'serious' has to be interpreted. Indeed, the links between article $1 \mathrm{~F}(\mathrm{~b})$ and international criminal law do not flow from the wording of this provision.

31 '[I]n the absence of a world government and of a sovereign international court of justice, that power of discretion, which was an essential safeguard both for the real refugee and for the country of refuge, must, perforce, be left to States. The only practical solution was to trust the countries which were willing to grant hospitality.' Statement of Mr Rochefort of France, (UN Doc E/ AC.7/SR.166), p. 4.

32 Handbook, para. 155-156.

33 Smuggling Protocol, art. 3(a).

34 Ibid, art. 6(1)(a).

35 Ibid, art. 6(1)(b).

36 Ibid, art. 6(1)(c).

37 Status of Ratification Smuggling Protocol, <https://treaties.un.org/Pages/ViewDetails.aspx?src= TREATY\&mtdsg_no=XVIII-12-b\&chapter=18\&clang=_en >; The Directorate-General for Internal Policies of the Policy Department Citizen's Rights and Constitutional Affairs, 'Fit for Purpose? The Facilitation Directive and the Criminalisation of Humanitarian Assistance to Irregular Migrants', (European Union 2016), p. 23.

38 Council Directive 2002/90/EC, art. 1(1); Ireland also adopted this Directive, see recital 7.

Ibid; Framework Decision, art. 1; See: 'Fit for Purpose?', Annex II. 
According to the UNHCR, ${ }^{40}$ the preeminent rule for determining the level of seriousness is that the gravity of the crime should be judged against international standards and not simply by its characterization in the host state or country of origin. ${ }^{41}$ Furthermore, the UNHCR provides five key factors to take into account when deciding on the seriousness of a crime: 'the nature of the act, the actual harm inflicted, the form of procedure used to prosecute the crime, the nature of the penalty for such a crime and whether most jurisdictions would consider the offence in question as a serious crime. ${ }^{42}$ Accordingly, the UNHCR states that a serious crime refers to 'a capital crime or very grave punishable act.' 43

Accordingly, scholarly opinion also prefers to consider acts which are grave in an international sense, which typically attract lengthy custodial sentences and which compromise physical integrity, life and liberty as serious crimes, but emphasizes that domestic laws and their notions of serious crimes must also be assessed. ${ }^{44}$ Furthermore, evidence that the UNHCR guidelines must be utilized when determining the level of seriousness, can also be found in domestic jurisprudence. Reference is made to international standards in the form of an international treaty criminalizing the conduct or an indication that such a treaty will be concluded. ${ }^{45}$ Moreover, the UK High Court examined the seriousness of a crime by applying comparable standards including 'the elements of the crime, the factual matrix, the circumstances of the alleged offender and the level of punishment to be inflicted if convicted. 46

Therefore, when examining the 'serious' character of migrant smuggling, it is essential to look at its characterization according to international standards. ${ }^{47}$ Hence, the fact that the UN decided to conclude the Smuggling Protocol under its aegis contributes to the seriousness of the crime. The preamble of the Smuggling Protocol reveals that the instrument was deemed necessary in order to create an international mechanism for the prevention of migrant smuggling, requiring a comprehensive international approach. ${ }^{48}$ Additionally, the preamble of the Smuggling Protocol reveals the concern about the great harm activities of migrant

40 UNHCR documents are non-binding but are considered highly authoritative and are often referred to by domestic and international courts.

41 Guidelines ibid; Background Note ibid, para. 38.

42 Ibid; ibid, para. 39.

43 Handbook, para. 155.

44 N. Djordevic, 'Exclusion under Article $1 \mathrm{~F}(\mathrm{~b})$ of the Refugee Convention: The Uncertain Concept of Internationally Serious Common Crimes', JICJ (12) 2014, p. 1066; G. Goodwin-Gill and J. McAdam, p. 177; Tiberghien, La Protection des Réfugiés en France, (2nd edn 1988) p. 104; A. Grahl-Madsen, The Status of Refugees in International Law, (Vol I, Slijthof 1966) p. 294; A.T. Gallagher and F. David, The International Law of Migrant Smuggling, Cambridge University Press 2014, p. 171.

45 The Dutch Council of State, 10 February 2014, nr. 201208875/1/V1, para. 2.4; The Dutch Council of State, 27 September 2013, nr. 201202758/1/V2, para. 2.4; German Federal Administrative Court, 16 February 2010, nr. 10 C 7.09, para. 47; Belgian Commissioner-General for Refugees and Stateless Persons, 2009, nr. 33 730, para. 13.

46 UK High Court, 6 December 2011, nr. UKHC 2937, para. 27.

47 Guidelines, para. 14; Background Note, para. 38.

48 Smuggling Protocol, preamble para. 1, 7; UNGA Res 53/111 (20 January 1999) UN Doc A/RES/ 53/111 para. 10 . 
smuggling cause to the States Parties. ${ }^{49}$ Moreover, the preamble conveys the serious character of migrant smuggling by emphasizing that it endangers the lives and security of the migrants involved. ${ }^{50}$ The serious character of migrant smuggling in the Mediterranean was also addressed in a different international setting, namely by the UN Security Council. It adopted resolutions 2240, 2312 and 2380 in which measures under Chapter VII UN Charter were taken to combat migrant smuggling taking place off the coast of Libya. ${ }^{51}$ Lastly, the adoption of a European legal framework indicates that the character of migrant smuggling is deemed sufficiently serious to establish a collective approach to combat the crime. ${ }^{52}$

Furthermore, the UNHCR standards for assessing the seriousness of the crime must be taken into account. ${ }^{53}$ The nature of migrant smuggling in the Mediterranean is widespread as research has shown that around $90 \%$ of the migrants coming to Europe use the services of smugglers. ${ }^{54}$ The enormous amount of victims that have perished as a result of migrant smuggling in the Mediterranean is a strong indicator that severe and actual damage is caused. ${ }^{55}$ However, as a matter of fact, not all operations of migrant smuggling involve actual and severe harm or damage. ${ }^{56}$ For instance, in the Netherlands a man was excluded from refugee status because he was involved in illegally transferring six persons by air from a country in Southern Asia to the Netherlands. ${ }^{57}$ He was convicted and a relatively low prison sentence of nine months was imposed on him. ${ }^{58}$ Still, in line with Directive 2002/90/EC and Framework Decision 2002/946/JHA, the EU Member States implemented domestic legislation to criminalize migrant smuggling which enables the national authorities to prosecute and penalize perpetrators of migrant smuggling. ${ }^{59}$ The penalty comprises a prison sentence of up to 10 years. ${ }^{60}$ Hence, as a consequence of the wide ratification of the Smuggling Proto$\mathrm{Col}^{61}$ and the adoption of the European legal framework on migrant smuggling, ${ }^{62}$ international standards seem to underscore that the EU Member States consider migrant smuggling to be a serious crime. Nonetheless, the level of actual harm or damage inflicted may differ widely which leads to the conclusion that a case by

Smuggling Protocol ibid preamble para. 5.

Ibid preamble para. 6.

UNSC Res 2240 (9 October 2015) UN Doc S/RES/2240 para. 1; UNSC Res 2312 (6 October 2016)

UN Doc S/RES/2312, para. 1; UNSC Res 2380 (5 October 2017) UN Doc S/RES/2380 para. 1.

Directive 2002/90/EC, recital 1 and 2; Framework Decision, recital 1, 2 and 3.

Background Note, para. 39.

Europol 2016, p. 4.

IOM, Migration Flows Europe; UNHCR, Operational Portal Refugee Situation.

A.T. Gallagher and F. David, p. 171.

M.P. Bolhuis and J. van Wijk, 'Alleged Terrorists and Other Perpetrators of Serious Non-Political Crimes: The Application of Article $1 \mathrm{~F}(\mathrm{~b})$ of the Refugee Convention in the Netherlands', Journal of Refugee Studies 2016, p. 29; This poses the question whether for migrant smuggling to qualify as a serious crime, aggravated circumstances such as the use of unseaworthy vessels and equipment are required, see also Art. 6(3) Smuggling Protocol and A.T. Gallagher and F. David, p. 51.

M.P. Bolhuis and J. van Wijk ibid.

Framework Decision, art. 4, art. 1 and art. 9; 'Fit for Purpose?', Annex 2 96-98.

Ibid, art 1; ibid, Annex 2 98-100.

Status of Ratification Smuggling Protocol.

Directive 2002/90/EC; Framework Decision. 
case assessment is necessary to determine the seriousness of a particular Mediterranean smuggling operation.

\subsection{Migrant smuggling as a 'non-political crime'}

In its origins, the concept of 'non-political crimes' was linked to extradition law and its definitions of political crimes. ${ }^{63}$ The preparatory works of the Refugee Convention reveal that article $1 \mathrm{~F}(\mathrm{~b})$ was designed as a means to bring refugee law in line with the principles of extradition law: '[T] criminals subject to extradition would naturally continue to be applicable. ${ }^{64}$ The 1996 British case T $v$ Secretary of State clearly utilized extradition law in an exclusion case. ${ }^{65}$ The UK Supreme Court decided:

'It was common ground that the words 'non-political crime' must bear the same meaning as they do in extradition law. Indeed, it appears from the travaux préparatoires that the framers of the convention had extradition law in mind when drafting the convention, and intended to make use of the same concept, although the application of the concept would, of course, be a different purpose. ${ }^{66}$

However, the text of article $1 \mathrm{~F}(\mathrm{~b})$ does not make any reference to extradition law and nothing in the preparatory works suggests that it was the intention of the drafters to oblige the States Parties to always exclude an individual if an extradition would have been possible on the basis of an extradition treaty. ${ }^{67}$ Furthermore, as there are no universally binding definitions of the notion of (non-)political crime, article $1 \mathrm{~F}(\mathrm{~b})$ cannot require direct application of extradition law. Moreover, the concepts of extradition and exclusion are distinct and serve different purposes. Extradition is concerned with the surrender of a fugitive for criminal prosecution or the enforcement of a sentence, with a view to prevent those seeking to evade justice by leaving the country being able to do so with impunity. On the other hand, exclusion is based on the notion that some individuals are not deserving of international refugee protection and its application deprives them of the rights and benefits of the Refugee Convention. Therefore, despite the fact that extradition law may indicate which types of crimes fall under the category of non-political crimes, this interpretative exercise can only take place by analogy. ${ }^{68}$ Again, the UNHCR provides some useful guidelines for identifying political and non-political crimes. According to the UNHCR, an offence is non-political when it

Universal Declaration of Human Rights, United Nations General Assembly, adopted 10 December 1948 (UNGA Res 217 A(III)) art. 14(2); Goodwin-Gill and McAdam, pp. 173-174; W. Kälin and J. Künzli, 'Article $1 F(b)$ : Freedom Fighters, Terrorists, and the Notion of Serious Non-Political Crimes', IJRL (12) 2000, p. 69.

64 Statement of Mr. Henkin of the United States: UN Doc E/AC.32/SR.5, para. 16; See also: Statement of Mr. Rochefort, para. 4.

65 UK House of Lords, 22 May 1996, nr. UKHL 2 ALL ER, para. 865, 753.

66 Ibid, para. 778.

67 Henkin ibid; Rochefort ibid; Kälin and Künzli, p. 70; Goodwin-Gill and McAdam, p. 174.

68 Kälin and Künzli ibid; Goodwin-Gill and McAdam ibid; Background Note, para. 42. 
has been committed for personal reasons and gain and not out of genuine political motives, when a close and direct causal link between the offence and the alleged political purpose is absent and when the offence is disproportionate to this purpose. ${ }^{69}$ These UNHCR guidelines are in line with the definitions of political and non-political offences in other normative instruments. For instance, at the European level, the political crime exception is part of article 3(1) of the 1957 European Convention on Extradition (ECE) ${ }^{70}$ Furthermore, article 1 of the ECE Additional Protocol reveals that crimes against humanity and war crimes are excluded from the notion of political offences. ${ }^{71}$ Moreover, the Constitution of Interpol contains a prohibition for the organization to engage in any intervention or activities of a political, military, religious or racial character. ${ }^{72}$ A subsequently adopted resolution on the interpretation of this prohibition excludes offences which have no direct connection with the political life of the perpetrators' country but are committed with definite political motives, from the notion of political offences. $^{73}$

In academic literature examining domestic criminal codes or statutes, two different types of political offences can be distinguished. Absolute or purely political offences involving acts such as espionage, treason, election fraud or founding or membership of a prohibited political party. ${ }^{74}$ These acts are regarded as direct assaults on the integrity of the state. ${ }^{75}$ Relative political offences are common crimes criminalized under ordinary law. However, they have been committed with a clear political motivation in order to bring about a balance of political power within a state. ${ }^{76}$ Again, the T $v$ Secretary of State case of the UK Supreme Court is highly useful as it sheds light on the criteria to determine when a common crime is 'political.' For the Court:

'A crime is a political crime for the purposes of Article $1 F(b)$ of the Geneva Convention if, and only if: it is committed for a political purpose, that is to say, with the object of overthrowing or subverting or changing the Government of a State or inducing it to change its policy; and there is a sufficiently close and direct link between the crime and the alleged political purpose. In determining whether such a link exists, the court will bear in mind the means used to achieve the political end, and will have particular regard to whether the crime was aimed at a military or governmental target, on the one hand, or

70 European Convention on Extradition, 1957 ETS 24, art. 3(1).

71 Additional Protocol to the European Convention on Extradition 1975 ETS 86, art. 1.

72 The Constitution of the ICPO-Interpol 1956, art. 3.

73 Interpol General Assembly 1984 RES AGN/53/RES/7 part II, para. 3.

74 Kälin and Künzli, p. 65; A.E. Evans, 'Reflections upon the Political Offense in International Practice', AJIL (57) 1963, pp. 15-18.

Ibid; ibid.

Ibid; ibid. 
a civilian target on the other, and in either event, whether it was likely to involve the indiscriminate killing or injuring of members of the public.'77

Similar considerations can be found in Swiss and German jurisprudence. ${ }^{78}$ After having considered the content and scope of non-political crimes, it is essential to consider both the relevant legal instruments and empirical research to analyze whether migrant smuggling can be identified as a non-political crime. Significantly, the gain of a financial or other material benefit is required by the definition of the Smuggling Protocol. ${ }^{79}$ In other words, this financial or other material benefit is part of the requirements that identify certain acts as migrant smuggling. The preparatory works of the Smuggling Protocol reveal that this financial or other material benefit was included to prevent family members and non-governmental organizations from punishment and does not include any political aims. ${ }^{80}$ In the definition of Directive 2002/90/EC, intentionally assisting 'a person who is not a national of a Member State to enter, or transit across, the territory of a Member State' is not linked to the purpose of obtaining financial or material gain. ${ }^{81}$ Therefore, as opposed to the Smuggling Protocol, it does not seem to exclude political motives per se.

It is necessary to have a look at empirical research on the motivation of smugglers to see whether political motives may form part of it. In newspaper headlines, profit or gaining money is often described as the main target of the smugglers. ${ }^{82}$ As a matter of fact, research has shown that the economic factor is indeed often considered the main reason to become involved in migrant smuggling. ${ }^{83}$ Research has shown that this flows from the perception of the smuggler considering smuggling as a legitimate business as they help people escaping danger and misery. ${ }^{84}$ However, again, some nuance is essential as the principal motivation to participate may consist out of other decisive factors or a combination of them. ${ }^{85}$ For instance, situations have been identified that the motivation to participate in

77 Tv Secretary of State for Home Department, (n 61) [443].

78 Swiss Federal Tribunal (106 lb) [307], [308]; For the German Jurisprudence see its references in: T. Stein, Die Auslieferungsausnahme bei Politischen Delikten, Berlin Heidelberg: Springer-Verlag 1983, pp. 183-283.

79 Smuggling Protocol, art. 3(a); one of the constitutive elements of migrant smuggling is to obtain, directly or indirectly a financial or other material benefit.

80 In the Draft Smuggling Protocol, 'profit' was implemented in the definition of Migrant Smuggling UN Doc A/AC.254/4/Add.1/Rev.2, 4; Profit meant 'any property, benefit or advantage obtained', UN Doc A/AC.254/4/Add.1/Rev.3; UNODC, Travaux Préparatoires of the Negotations for the Elaboration of the United Nations Convention against Transnational Organized Crime and the Protocols thereto, 3 November 2000, p. 469.

81 Directive 2002/90/EC, art. 1(a).

82 See amongst others: M. Bulman, 'People Smuggling in Europe Comparable to the Illegal Drugs Market, Warns Report', The Independent 9 March 2017; C.N. Chonghaile,'People Smuggling: How it Works, Who Benefits and How it can be Stopped', The Guardian 31 July 2015.

83 Achilli 2018, p. 84; T. Baird, Human Smuggling in the Eastern Mediterranean, Routledge 2017, p. 83.

84 Achilli 2018, p. 80; Achilli 2015, p. 6; Sanchez, p. 15.

85 Achilli 2016, p. 101. 
human smuggling flows from the moral duty to help fellow citizens. ${ }^{86}$ Furthermore, it can also be a combination of the profit and this moral motivation. One can think of the situation where the individual is principally involved because of the latter but at the same time simply needs to gain money to pay a smuggler. ${ }^{87}$ Lastly, there have been a few indications that migrant smuggling may be perpetrated for a political purpose. ${ }^{88}$ For instance, Van Liempt discussed an example of an Eritrean woman who stated that she was aided by her party to leave Eritrea. ${ }^{89}$ However, it is difficult to substantiate these claims as the political party will never admit its involvement. Hence, the financial benefit seems to be the main incentive for participation in smuggling networks. However, as a consequence of the myriad of several motivations and incentives to become part of smuggling operations, it is impossible to conclude that migrant smuggling in the Mediterranean is always conducted for non-political reasons and motives.

\section{Individual responsibility}

After having considered whether migrant smuggling in the Mediterranean as such can be regarded as a serious non-political crime, individual responsibility must be established in order to exclude a smuggler from refugee status on the basis of article $1 \mathrm{~F}(\mathrm{~b}) .{ }^{90}$ It is important that this exercise takes place with great caution as the consequences of exclusion for the particular individual are severe as he falls outside the protective framework of the Refugee Convention. ${ }^{91}$ Nonetheless, despite the wordings of article $1 \mathrm{~F}$ that there must be 'serious reasons to consider that (...) he has committed a serious non-political crime,' the Refugee Convention remains silent in this regard. More specifically, article 12(3) Qualification Directive provides that the exclusion clauses apply to 'persons who incite or otherwise participate in the commission of the crimes or acts mentioned therein. ${ }^{92}$

With the help of relevant legal instruments, case law and empirical research on migrant smuggling, it will be discussed to what extent membership of a smugglers network or a specific role within such a network may establish individual responsibility and whether different types of specific conduct are sufficiently serious to trigger the application of article $1 \mathrm{~F}(\mathrm{~b})$ Refugee Convention.

87 Achilli 2015, p. 7; H. Lucht, 'Darkness before Daybreak: African Migrants Living on the Margins in Southern Italy Today’, Berkely: University of California Press Mediterranean Politics 2012.

88 Van Liempt, pp. 127-128; Papadopoulou, 'Kurdish Asylum Seekers in Greece: The Role of Networks in the Migration Process', (Paper presented at UNU/Wider Conference on Poverty, International Migration and Asylum, Helsinki 2002).

89 Van Liempt ibid.

90 This approach is also taken by the CJEU and national decision-making authorities in asylum cases, see: CJEU, B and D, para. 85-87; CJEU, Lounani, para. 72; Dutch Asylum Policy Guidelines C2.7.10.2.4; See also: Background Note, para. 50-61.

91 Guidelines, para. 2; Background Note, para. 3.

92 Qualification Directive, art. 12(3). 


\subsection{Membership of a smuggling network versus individual participation}

Empirical research shows that smuggler networks cannot be qualified as hierarchical and highly structured entities. ${ }^{93}$ Rather, these networks can be described as adaptive and flexible coalitions in order to respond to unexpected circumstances such as the change of migratory routes. ${ }^{94}$ The working relationship between the several individuals are embedded in ad hoc agreements as opposed to long term contracts. ${ }^{95}$ In terms of individual responsibility, the question arises whether membership of such a smuggling network is sufficient for individual responsibility under article $1 \mathrm{~F}(\mathrm{~b})$ Refugee Convention. In this light, case law of the Court of Justice of the European Union (CJEU) provides principal guidance. The cases $B$ and $D$ and Lounani of the CJEU, both consider exclusion from refugee status under article $1 \mathrm{~F}(\mathrm{~b})$ and $1 \mathrm{~F}(\mathrm{c})$ for participating in acts of terrorism. ${ }^{96}$ First of all, the CJEU held that the national authorities cannot apply the exclusion clauses until they have carried out a full investigation and assessment of the specific facts and circumstances of each individual case in order to establish individual responsibility. ${ }^{97}$ As regards membership in an organization involved in crimes falling under article $1 \mathrm{~F}(\mathrm{~b})$ and $1 \mathrm{~F}(\mathrm{c})$, the CJEU ruled that 'the mere fact that the person concerned was a member of such an organization cannot automatically mean that that person must be excluded from refugee status pursuant to those provisions.'98 Hence, mere membership is clearly not sufficient for establishing individual responsibility which triggers the application of article $1 \mathrm{~F}(\mathrm{~b})$ as it is essential to consider individual facts and circumstances.

A first step to establish individual responsibility for migrant smuggling is to consider the various grounds for individual responsibility in the instruments criminalizing the offence, being the Smuggling Protocol and Directive 2002/90. The specific conduct that establishes the first ground for individual responsibility under the Smuggling Protocol, entails organizing or directing migrant smuggling, the production and provision of fraudulent documents or unlawful residence. ${ }^{99}$ The first ground of individual responsibility in Directive 2002/90 differs from the Smuggling Protocol and requires instigation of assistance of a non-EU citizen in entering or transit across EU Member States or, for financial gain, assisting such a person to unlawfully reside on EU territory. ${ }^{100}$ The second ground for individual responsibility as contained in the Smuggling Protocol and Directive 2002/90 are similarly formulated and require an individual to act as an accomplice in migrant smuggling or enabling the offence by means of the conduct just mentioned. ${ }^{101} \mathrm{In}$ both the Smuggling Protocol and Directive 2002/90, the third ground for individ-

93 Triandafyllidou and Maroukis, p. 143; Abel Aziz et al., p. 25.

94 Interpol, p. 10; Achilli 2016, p. 100; Triandafyllidou and Maroukis, p. 73; Baird, p. 84; Pastore et al., p. 113.

95 UNODC, p. 20; Sanchez, p. 14; Achilli 2018, p. 86; Pastore et al., p. 106.

96 CJEU, B and D, para.43-68; CJEU, Lounani, para. 28-39.

97 CJEU, B and D, para. 87 and 94; CJEU, Lounani, para.72.

98 CJEU, $B$ and $D$, para. 88.

99 Smuggling Protocol, art. 6(2)(c).

100 Directive 2002/90/EC, art. 2(a).

101 Smuggling Protocol, art. 6(2)(b); Directive 2002/90/EC, art. 2(b). 
ual responsibility is attempting to commit. ${ }^{102}$ This ground was added because the modus operandi of migrant smuggling in the Mediterranean is characterized by the fact that operations are often stopped by national authorities before completion. ${ }^{103}$

Empirical research has identified the main roles individuals can have in smuggling operations, which are the following: the organizer or leader, the recruiter or broker, the money handler, the passeur and the so-called freelancers. ${ }^{104}$ First, the role of organizer or leader of smuggling networks seems to have the most potential to fall under the first ground for individual responsibility. This is because empirical research shows that the organizer or the leader is involved in the overall coordination of a particular smuggling operation and is occupied with the daily management of the smuggling network which match the concepts of organizing and directing. ${ }^{105}$ Instigating implies an element of prompting others to commit an act with the likely result that migrant smuggling will be committed or be a probable consequence of this act. ${ }^{106}$ Whether an organizer or leader meets these criteria depends on whether he has to convince the individuals involved to actively participate in a smuggling operation. To the contrary, empirical research has shown that the various individuals involved have many different motivations and goals. ${ }^{107}$ In cases where every individual involved is driven by this individual motivation, the element of instigation may be absent.

Second, the recruiter or broker may fall under the second ground for individual responsibility which requires the participation as an accomplice. His or her role is fundamental as he is responsible for the creation of relations between the smugglers and the migrants, which is key to attract new clients. ${ }^{108}$ The recruiter of broker is responsible for the individual arrangements between the two parties and determines the method of payment. ${ }^{109}$ Another role that may fall under this concept is the money handler. He cannot be omitted as he is responsible for the successful completion of the financial transaction between the migrant and the smugglers. ${ }^{110}$ The importance of this role is underlined by the fact that the gain of financial or material benefit is one of the key elements of the crime of migrant

102 Ibid, art. 6(2)(a); ibid, art. 2(c).

103 See: A.T. Gallagher and F. David, p. 370.

104 This is not an exhaustive overview of all the potential roles smugglers can have, but an overview of the roles which are identified in the majority of the studies, see: Baird, p. 84; EUROPOL, p. 4; UNODC, pp. 20-21; Europol- INTERPOL, pp. 7-8; Achilli 2015, p. 5; Achilli 2016, p. 101; Achilli 2018 , p. 80. See for a comparable division of functions within smuggling networks Italian criminal case law on migrant smuggling: SHERLOC UNODC Case Law Database nr. 615/2017 DDA R.G.N.R, <www.unodc.org/cld/case-law-doc/moneylaunderingcrimetype/ita/2017/proc._nr._ 6152017_dda_r.g.n.r.html?lng=en\&tmpl=sherloc >.

105 Europol-INTERPOL, p. 7; OECD, p. 7; UNODC, p. 20; Europol, p. 9; Achilli 2016, p. 101; Baird, p. 87; Achilli 2018, p. 85; Sanchez, p. 14.

106 Background Note, para. 52.

107 Baird, p. 84.

108 Achilli 2016; Europol, p. 10; OECD, p. 7; UNODC, p. 21; Achilli 2018, p. 85; Triandafyllidou and Maroukis, p. 134.

109 Baird, p. 87.

110 Europol, p. 9; OECD, p. 8; Achilli 2018, p. 85; Triandafyllidou and Maroukis, p. 134. 
smuggling. ${ }^{111}$ Furthermore, the passeur or driver, responsible for the maritime and land transport of the migrants, may be qualified as an accomplice. He cannot be omitted in the smuggling network, otherwise the actual smuggling from place A to place B cannot take place. ${ }^{112}$ Freelancers may fulfill many different tasks such as being providers or sellers of boats, spotters signaling potential presence of police forces, or suppliers of services such as food and accommodation. ${ }^{113}$ Depending on their specific involvement, they may also be regarded as accomplices as they operate as facilitators of the smuggling operation.

A second step is to consider whether the particular conduct of the various individuals involved is sufficiently serious to trigger the application of article $1 \mathrm{~F}(\mathrm{~b})$ Refugee Convention. In this regard, the CJEU ruled in the $B$ and $D$ case that individual responsibility under article $1 \mathrm{~F}$ must be assessed on the basis of subjective and objective criteria. ${ }^{114}$ Furthermore, the CJEU developed a set of criteria on the basis of which the assessment of individual responsibility must take place which entail:

'the true role played by the person concerned in the perpetration of the acts in question, his position within the organization, the extent of knowledge he had, or was deemed to have, of its activities, any pressure to which he was exposed, or other factors likely to have influenced his conduct.' ${ }^{115}$

In general, being the organizer or leader presumes the preoccupation of the most central role in the smuggling network as he is responsible for the coordination of the smuggling operations and the management of the network. ${ }^{116} \mathrm{He}$ cannot be missed in the execution of an operation as it is doomed to fail without an organizer or leader. Having these responsibilities, there is no doubt that he knows that the network is involved in migrant smuggling. This particular intensity of involvement seems to justify the application of article $1 \mathrm{~F}(\mathrm{~b})$. However, in cases where the organization is led by more organizers or leaders, factors such as the possible exertion of pressure must be taken into account. ${ }^{117}$ As stressed above, the roles of recruiter or broker, money handler and passeur are essential for the commission of migrant smuggling. Significantly, it is possible that they work for several smuggling networks at the same time. This shared commitment may have consequences for the extent of knowledge they have of all the activities of a particular smuggling network compared to the organizer or leader. Furthermore, in cases where migrants fulfill these roles, the exposure to pressure is likely to take place. An example is when the migrant has to gain money for his own travel or has debts because a previous attempt failed and the payment was already comple-

111 Smuggling Protocol, art. 3(a); see also paragraph 2.3.

112 Europol, p. 9; OECD, p. 7; Achilli 2016; Baird, p. 87; UNODC, p. 21.

113 OECD, p. 8; UNODC, p. 24; Achilli 2018, p. 85; Achilli 2016, p. 101.

$114 B$ and $D$, para. 96.

115 CJEU, B and D, para. 97.

116 See: Achilli 2018 and his description of the smuggling network led by Abu Hamza.

117 Baird, p. 86. 
ted. ${ }^{118}$ Hence, their roles seem to trigger the application of article $1 \mathrm{~F}(\mathrm{~b})$, however, extreme caution must be maintained when assessing the extent of knowledge and any exposure to pressure. Lastly, as mentioned above, the role of freelancers within a smuggling network varies widely. ${ }^{119}$ As a result, different gradations of individual responsibility can be identified. For instance, boat owners or sellers occupy a prominent role as the availability of a vessel is key for migrant smuggling in the Mediterranean. On the contrary, providers of food and accommodation and spotters are not indispensable in every smuggling operation. Furthermore, freelancers are often not members of the smugglers network. ${ }^{120}$ This has direct consequences for the extent of knowledge they have of the activities of the organization. Still, it is not excluded that partnerships are concluded and freelancers continuously work for the same networks. ${ }^{121}$ Hence, for this category of persons, extra caution must be maintained while examining whether their conduct triggers the application of article $1 \mathrm{~F}(\mathrm{~b})$.

\section{Conclusion}

International standards such as the Smuggling Protocol, UNSC Resolutions, European instruments such as Directive 2002/90 and its accompanying Framework Decision, domestic laws and jurisprudence seem to suggest that migrant smuggling in the Mediterranean can be considered a serious crime. Still, not every single Mediterranean smuggling operation causes actual and severe damage such as the loss of lives. Significantly, empirical research shows that the main motivation of smugglers is a financial or material benefit rather than any political aims. However, although rarely, also cases of migrant smuggling involving political motivations have been identified. Hence, determining the seriousness as well as the (non-)political motives to see whether article $1 \mathrm{~F}(\mathrm{~b})$ applies to individuals involved in migrant smuggling ultimately requires a case-by-case assessment.

As regards individual responsibility, the mere fact that an individual is a member of an organization involved in migrant smuggling is not sufficient for the application of article $1 \mathrm{~F}(\mathrm{~b})$. To assess whether article $1 \mathrm{~F}(\mathrm{~b})$ can be triggered, the role the individual played in the perpetration of the acts, his position within the organization and the knowledge he has of its activities must be examined. First, due to the intensity of involvement and knowledge of the activities of the smuggler network, it seems that the conduct comprising the functions of organizer or leader likely triggers the application of article $1 \mathrm{~F}(\mathrm{~b})$. Second, the positions of recruiter, money handler, passeur or driver can be identified as accomplices as they are significant to let a smuggling operation run smoothly which also may require the application of article $1 \mathrm{~F}(\mathrm{~b})$. Still, for either the positions of organizer, leader or accomplice, attention must be paid to factors such as the exposure to pressure,

118 Abel Aziz et al., p. 59; Triandafyllidou and Maroukis, p. 105, 134; Van Liempt, p. 124, 125; Achilli 2015, p. 7; Sanchez, p. 15; Achilli 2018 p. 87.

119 Achilli 2016; OECD, p. 8; UNODC, p. 24; Achilli 2018, p. 85; Achilli 2016, p. 101.

120 UNODC, p. 21.

121 Achilli 2018, p. 85. 
the fact that migrants themselves may function as accomplices or that accomplices may work for several networks. This even more applies to freelancers as they may not even be members of the smuggling network which has consequences for the intensity of their involvement in the network and their knowledge of its activities. Hence, the positions of organizer, leader or accomplice generally imply more intensive involvement in and more extensive knowledge of smuggling operations and therefore may trigger the application of article $1 \mathrm{~F}(\mathrm{~b})$. However, given the severe consequences of exclusion from international protection, besides identifying the specific function an individual had in a smuggling operation, still the specific conduct and knowledge of the individual involved must be identified and assessed, and factors influencing the behavior establishing involvement in migrant smuggling must be taken into account. Only such a scrupulous assessment to see whether the application of article $1 \mathrm{~F}(\mathrm{~b})$ may be triggered in cases of migrant smuggling in the Mediterranean is in line with the rationale of article $1 \mathrm{~F}$ requiring a restrictive interpretation and application of the exclusion clauses. 